University of Nebraska - Lincoln

DigitalCommons@University of Nebraska - Lincoln

\title{
Biomass and Cellulosic Ethanol Production of Forage Sorghum Under Limited Water Conditions
}

Jon Cotton

USDA-ARS, Jon.Cotton@ars.usda.gov

Gloria Burow

USDA-ARS

Veronica Acosta-Martinez

USDA-ARS, veronica.acosta-martinez@ars.usda.gov

Jennifer Moore-Kucera

Texas Tech University

Follow this and additional works at: https://digitalcommons.unl.edu/usdaarsfacpub

Cotton, Jon; Burow, Gloria; Acosta-Martinez, Veronica; and Moore-Kucera, Jennifer, "Biomass and Cellulosic Ethanol Production of Forage Sorghum Under Limited Water Conditions" (2013). Publications from USDA-ARS / UNL Faculty. 1240.

https://digitalcommons.unl.edu/usdaarsfacpub/1240

This Article is brought to you for free and open access by the U.S. Department of Agriculture: Agricultural Research Service, Lincoln, Nebraska at DigitalCommons@University of Nebraska - Lincoln. It has been accepted for inclusion in Publications from USDA-ARS / UNL Faculty by an authorized administrator of DigitalCommons@University of Nebraska - Lincoln. 


\title{
Biomass and Cellulosic Ethanol Production of Forage Sorghum Under Limited Water Conditions
}

\author{
Jon Cotton • Gloria Burow • Veronica Acosta-Martinez • Jennifer Moore-Kucera
}

Published online: 28 December 2012

(C) Springer Science+Business Media New York (outside the USA) 2012
This article is a U.S. government work, and is not subject to copyright in the United States.

\begin{abstract}
This study presents results from a 2-year evaluation of biomass and cellulosic ethanol (EtOH) production potential of forage sorghum (Sorghum bicolor L. Moench) cultivars differing in brown midrib trait (i.e., bmr12) under dryland (no irrigation) and limited irrigation $(2.88 \mathrm{~mm}$ day $^{-1}$; subsurface drip) in the semiarid Southern High Plains of the USA. Commercial cultivar Sorghum Partners 1990 (SP 1990, conventional non-bmr) produced significantly more biomass (29-62 \%) than a bmr12 cultivar PaceSetter $b m r$ (PS $b m r$ ) under irrigated and dryland conditions during both years of this study. However, PS $b m r$ biomass had higher cellulosic EtOH conversion efficiency than SP 1990 in both years according to simultaneous saccharification and fermentation analysis. Irrigation resulted in 26-49\% more biomass and 28-72\% more cellulosic EtOH production during both growing seasons, indicating that limited irrigation had favorable effects on both biomass and biofuel production. In the first year, when precipitation was below average, both cultivars produced similar amounts of cellulosic EtOH. During the second year, when precipitation was above average, higher biomass production of SP 1990 resulted in $28 \%$ higher cellulosic EtOH production than PS $b m r$ when averaged across both irrigated and dryland conditions. The large range of cellulosic EtOH production (1,600 to 3,380 L $\mathrm{ha}^{-1}$ ) during the 2 years of this study was primarily driven by differences in water availability that resulted from precipitation and irrigation. Our findings indicates that
\end{abstract}

J. Cotton · G. Burow $\cdot$ V. Acosta-Martinez

USDA-ARS Cropping Systems Research Laboratory,

3810 4th Street,

79415, Lubbock, TX, USA

J. Cotton $(\bowtie) \cdot$ J. Moore-Kucera

Department of Plant and Soil Science, Texas Tech University,

Campus Box 42122, 79409, Lubbock, TX, USA

e-mail: Jon.Cotton@ars.usda.gov chemical composition and biomass yield potential of sorghum cultivars are critical factors that affect biomass and biofuel production under limited water conditions.

Keywords Biofuels · Ethanol · Forage sorghum · Ogallala aquifer - Simultaneous saccharification and fermentation . Water deficit · Deficit irrigation

$\begin{array}{ll}\text { Abbreviations } \\ \text { EtOH } & \text { Ethanol } \\ \text { SHP } & \text { Southern High Plains } \\ b m r & \text { Brown midrib trait } \\ \text { SP 1990 } & \text { Sorghum cultivar Sorghum Partners } 1990 \\ \text { PS } b m r & \text { Sorghum cultivar PaceSetter } b m r \\ \text { ET } & \text { Evapotranspiration } \\ \text { ADF } & \text { Acid detergent fiber } \\ \text { NDF } & \text { Neutral detergent fiber } \\ \text { ADL } & \text { Acid detergent lignin } \\ \text { SSF } & \text { Simultaneous saccharification and } \\ & \text { fermentation } \\ \text { Percent CCE } & \text { Cellulosic ethanol conversion efficiency } \\ \text { TEY } & \text { Theoretical cellulosic ethanol yield }\end{array}$

\section{Introduction}

Biofuels, which are produced from renewable plant resources such as grain or biomass, have gained attention in recent years as continuing decline in fossil fuel reserves coupled with increases in global energy demand and greenhouse gas emissions has threatened the sustainability of current energy production. The benefits of fixing atmospheric carbon to help offset increased greenhouse gas emissions make biofuel production systems an integral facet of energy research. 
To meet the energy challenge in the USA, the Energy Independence and Security Act of 2007 mandated that by $2030,30 \%$ of liquid fuels in the country will be replaced by biofuels $[1,2]$. This directive requires production of an estimated one billion tons of feedstock that, by law, cannot be produced on newly cleared or cultivated lands $[1,2]$. However, this energy production model is not without controversy as high-input food crops grown on fertile lands have primarily been used for biofuel applications up to this point, effectively causing direct competition between energy and food prices [3]. To avoid this problem, one alternative scenario is to transition agricultural lands limited by abiotic factors (e.g., water deficit) not used for food production to sustainable biofuel cropping systems using crops adapted to these stresses.

The semiarid Southern High Plains (SHP) region of the USA, specifically the Llano Estacado region of northwest Texas, has over 4.7 million ha in 20 counties currently under intensive row crop production [4]. Major limitations to agriculture in this region are the deficit water conditions due to the intensive use of the main irrigation water source (i.e., the Ogallala aquifer) [5] and the low fertility and low organic matter content of the soils. This region has become dominated by cotton (Gossypium hirsutum L.) monoculture cropping during the past 20 years, accounting for $20-25 \%$ of the total US cotton production [5]. However, the future of current cropping practices is uncertain, as they further deplete the Ogallala aquifer, reduce inherently low soil organic matter [6], and intensify wind erosion common in this region [7]. Sorghum (Sorghum bicolor L. Moench) biofuel cropping systems in the SHP were shown to positively impact soil quality parameters within 2 years of transitioning from cotton cropping systems [8] despite complete removal of aboveground biomass. These soil quality improvements were mainly attributed to increased root biomass inputs from sorghum compared to cotton [9] and suggest the potential sustainability of sorghum biofuel cropping systems in the SHP.

Sorghum has been recommended for use as a bioenergy feedstock, and its overall resilience and stress tolerance features make it well adapted to water-limited conditions $[10,11]$. This crop is suitable for production purposes as it is an annual row crop with a short growing season, offering cropping system flexibility (e.g., rotations) not possible with other feedstock candidate perennial crops such as switchgrass. This is important in the SHP, where cropping flexibility and integration with profitable cotton production must be considered for large-scale adoption. Additionally, new sorghum cultivars have been introduced to enhance its utility as biomass feedstock. For example, the brown midrib trait $(b m r)$ now available in a number of forage sorghum cultivars results in reduced wall lignin content. Lignin limits the access of enzymes to cell wall sugars during digestion processes $[12,13]$; therefore, biomass with lower lignin content can have greater EtOH conversion efficiencies and production potential. Multiple $b m r$ loci have been characterized to manipulate lignin biosynthetic enzymes such as caffeic acid $O$-methyl transferase or cinnamyl alcohol dehydrogenase [14, 15], with bmr12 and bmr6 being most commonly used in commercial lines. Specifically, this study assessed a forage sorghum cultivar containing a bmr 12 mutation which specifically reduces production of syringyl lignin, modifying syringyl/guaiacyl ratios and resulting in lower overall lignin content. Sorghum isolines with $b m r 12$ have shown higher residue yields with lower lignin content than the same lines with bmr6 mutations [16, 17]. While information is available on the biochemical characteristics of sorghum and their effects on potential biofuel production [11, 12, 18], less is known about how these properties are affected by stress such as water deficit.

The objectives of this study were: (1) to measure the biomass production and biochemical composition of two commercial forage sorghum cultivars under two deficit water levels (dryland and limited supplemental irrigation of $\left.2.88 \mathrm{mmday}^{-1}\right),(2)$ to evaluate differences in cellulosic EtOH conversion between a forage sorghum with a bmr 12 mutation and a conventional forage sorghum lacking bmr mutation, and (3) to quantify cellulosic EtOH production on a land area basis over two growing seasons for the combination of cultivar (i.e., $b m r$ and non-bmr) and water level.

\section{Materials and Methods}

Site Description, Sorghum Cultivation, and Climate Data

This study was conducted during 2009-2010 at the US Department of Agriculture Agricultural Research Service Station in Big Spring, TX $\left(32^{\circ} 16.75^{\prime} \mathrm{N}\right.$ latitude, $101^{\circ}$ $29.30^{\prime} \mathrm{W}$ longitude), a semiarid region with mean annual temperature of $17.1{ }^{\circ} \mathrm{C}$ and precipitation of $485 \mathrm{~mm}$. The soil is an Amarillo fine sandy loam (fine-loamy, mixed, superactive, thermic Aridic Paleustalfs), with $13 \%$ clay, $78 \%$ sand, $\mathrm{pH}$ of 7.5 , and an average total $\mathrm{C}$ of $3.64 \mathrm{~g}$ $\mathrm{kg}^{-1}$ soil within the top $15 \mathrm{~cm}$. The land used was under conventional cotton production for over 10 years prior to study initiation. The study was a split-plot randomized block experimental design with irrigation rate as the main plot and split for cultivar types and biomass removal treatments ( $n=3$ for each treatment combination). Irrigation treatments consisted of non-irrigated (dryland) and deficit-irrigated $\left(2.88 \mathrm{mmday}^{-1}\right)$ plots, with subsurface drip irrigation (35 $\mathrm{cm}$ depth) applied daily under each row. The deficit irrigation rate was not based on a 
target replacement evapotranspiration (ET) but represents the projected reduced irrigation capacity of the Ogallala aquifer in the SHP [5]. Total irrigation applied was 228 and $210 \mathrm{~mm}$ during the 2009 and 2010 growing seasons, respectively. Two commercial forage sorghum cultivars were selected according to the results from fully irrigated yield trials in the SHP [19]. Sorghum Partners 1990 (SP 1990) was used to maximize biomass production with typical or wild-type cell wall composition. This cultivar was compared to the highest yielding $b m r$ cultivar, PaceSetter $b m r$ (PS $b m r$ ), which has a $b m r 12$ mutation

Each plot $(6 \times 7 \mathrm{~m})$ had six rows of sorghum planted at a spacing of $101.6 \mathrm{~cm}$, which is typical spacing for row cropping in this region under water deficit conditions. Planting occurred after precipitation events, when sufficient soil moisture for seed germination was present near the surface for both irrigated and dryland treatments. In 2009, planting occurred on 3 June, emergence on 9 June, and harvest on 21 August. In 2010, planting initially occurred on 7 May, but seedlings were adversely affected by hail and the field was replanted on 24 May. Emergence occurred on 29 May, and plants were harvested on 19 August. The harvest times were based on the maximum vegetative growth similar to Bean and McCollum [19]. Prior to planting, tillage $(20 \mathrm{~cm})$ was conducted multiple times in early spring to build beds for wind erosion prevention and for planting preparation. Cultivation $(0-10 \mathrm{~cm})$ using sweeps in the furrow occurred early in the season, with subsequent weed removal done by hand. Fertilizer (123 and $56 \mathrm{kgha}^{-1}$ year ${ }^{-1} \mathrm{~N}$ and $\mathrm{P}_{2} \mathrm{O}_{5}$, respectively) was injected by chisel at $25 \mathrm{~cm}$ from the plant base approximately 1 month after emergence. For harvest, plant samples were taken to measure biomass yield and for use in analyses (See "Plant Sampling and Analysis" subsection), followed by cutting and application of the appropriate biomass removal treatment (50 and $100 \%$ ), which were implemented for determining impacts on soil properties [8]. The remaining residue was left standing through winter and early spring before incorporation into the soil [8].

Weather data were collected using an on-site weather station (2009) and from the US National Weather Service (2010) weather station located $9.2 \mathrm{~km}$ from the research site. ET was estimated using the Texas Alliance for Water Conservation website [20]. During 2009, ET replacement was approximately $50 \%$ for dryland and $75 \%$ for irrigated. In 2010, due to higher precipitation, ET replacement was approximately $75 \%$ for dryland and near replacement for irrigated plots.

\section{Plant Sampling and Analysis}

At harvest, a non-border row within each plot was randomly selected and sampled $(1 \mathrm{~m})$ at the root-shoot juncture to estimate aboveground biomass yield. Biomass was determined for leaf and stem samples (chopped to $10-\mathrm{cm}$ pieces) separately for each plot (oven dried at $65{ }^{\circ} \mathrm{C}$ for $96 \mathrm{~h}$ ). All subsequent analyses were performed on leaf and stem samples separately, and a ratio of leaf-to-stem biomass was used to determine the overall value for each plant property for the entire plot.

For plant biochemical analyses, subsamples (approx. $50 \mathrm{~g}$ ) were ground to pass through a $2-\mathrm{mm}$ sieve using a Wiley mill (Thomas Scientific, Inc., Swedesboro, NJ). Acid detergent fiber (ADF) [21], neutral detergent fiber (NDF) [22], and acid detergent lignin (ADL) [23] were determined in a private laboratory (Ward Laboratories, Kearney, NE) using the Ankom filter bag system (Ankom Technology, Fairport, NY). Cellulose (ADF-ADL) and hemicellulose (NDF-ADF) were subsequently calculated using these values.

Cellulosic EtOH yield was assayed in triplicate for all samples using the simultaneous saccharification and fermentation (SSF) method of Isci et al. [24]. Briefly, $0.5 \mathrm{~g}$ of ground plant sample was heat-sealed in an Ankom filter bag and weighed for initial total weight (sample + bag). Samples were pretreated by soaking in $30 \% \mathrm{NH}_{4} \mathrm{OH}$ for $24 \mathrm{~h}$, rinsed with deionized water until ammonia odor was no longer present, and dried at ambient temperature for $48 \mathrm{~h}$. Total weight was again taken to estimate sample mass loss to ensure proper pretreatment occurred. Bags had slits cut and were then placed in 25-ml DeLong flasks (Bellco, Vinland, NJ), submerged in $20 \mathrm{ml}$ of SSF media (1\% yeast extract and $2 \%$ peptone in $0.05 \mathrm{M}$ citrate buffer, $\mathrm{pH} 4.8$ ), capped, covered in aluminum foil, and sterilized by autoclave for $20 \mathrm{~min}$ at $121{ }^{\circ} \mathrm{C}$. Samples were cooled at ambient temperature for $30 \mathrm{~min}$, and sterile SSF medium was added to each flask to replace any that had been lost during autoclaving. Cellulase enzyme (Spezyme CP lot no. 4900901-224, Genencor, Rochester, NY), $0.5 \mathrm{ml}$, with an activity of 50 filter paper units per milliliter, was added to each flask, followed by $0.5 \mathrm{ml}$ of Saccharomyces cerevisiae $\mathrm{D}_{5} \mathrm{~A}$ yeast culture (provided by the National Renewable Energy $\mathrm{Lab}$ ) diluted to $2.4 \times 10^{9} \mathrm{cells} \mathrm{ml}^{-1}$. Fermentation occurred during 24-h incubation at $37{ }^{\circ} \mathrm{C}$ on a rotating shaker at $170 \mathrm{rpm}$. A 1-ml aliquot was then removed and diluted appropriately with sterile deionized water for the range of the standard curve of the Megazyme International (Wicklow, Ireland) protocol used to quantify EtOH content [25].

\section{Calculations and Statistical Analysis}

Using values from the SSF analysis and the amount of cellulose present calculated from ADF and ADL analyses, cellulose conversion efficiency (percent CCE) was calculated [26] using a maximum conversion rate of 


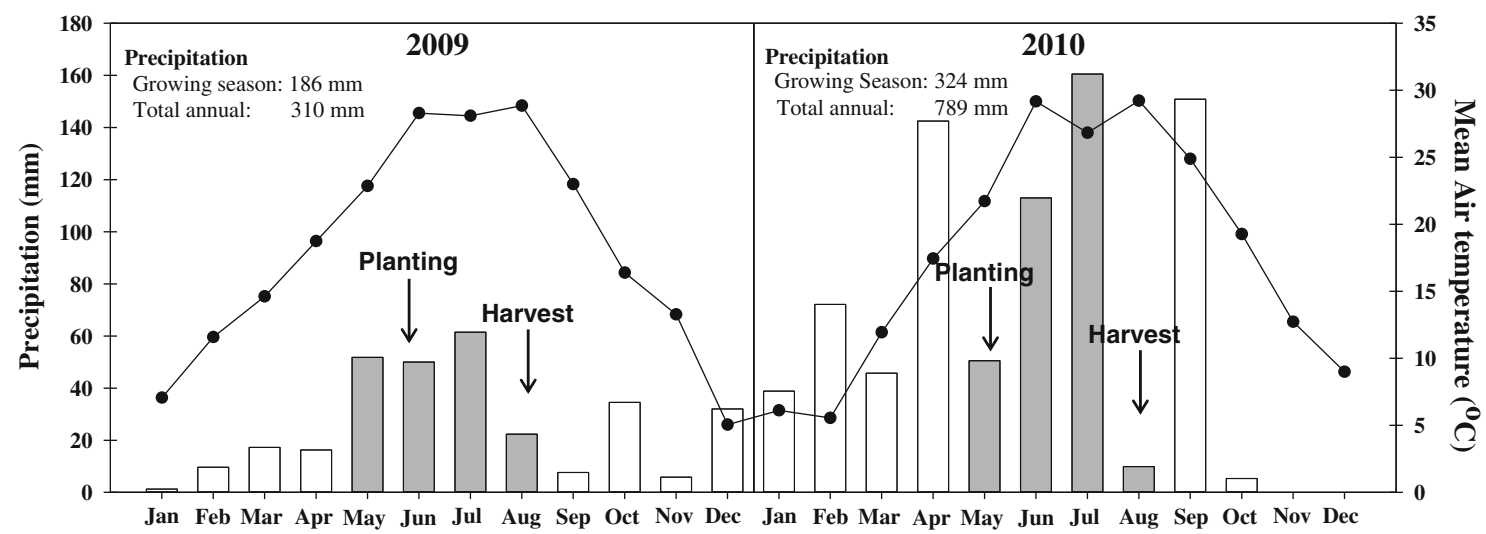

Fig. 1 Mean monthly temperature (line), total monthly precipitation (bar), precipitation during growing season (May-August, gray bars, text at top left), and total annual precipitation (text at top left) during

$0.511 \mathrm{~g} \mathrm{EtOH}$ per gram sugar [27] using the following equation:

$\% \boldsymbol{C C E}=\frac{E t O H(g) \text { produced during } S S F}{\text { cellulose }(g) \text { present } \times 0.511} \times 100$

Theoretical cellulosic EtOH yield (TEY) on a land area basis was calculated according to the equation:

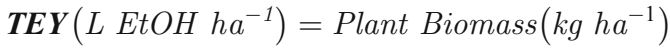

$$
\begin{aligned}
& \times(\% \text { cellulose } / 100) \times 0.511 \\
& \times(\% \mathrm{CCE} / 100) \times\left(0.789 \mathrm{LEtOH} \mathrm{kg}^{-1}\right)
\end{aligned}
$$

For the different parameters evaluated, the mean and standard error of the mean, standard least squares analysis of variance (ANOVA), and protected pairwise comparisons using Student's $t$ test were performed using $\mathrm{R}$ statistical software (ver. 2.13.1) [28].

\section{Results \\ Climate Data}

Higher precipitation occurred during the second year of this study in $2010(789 \mathrm{~mm})$ than the first year in 2009 (310 $\mathrm{mm}$ ), and specifically during the growing season from May to August (324 vs. $186 \mathrm{~mm}$ ) (Fig. 1). Seasonal precipitation was above and below the historical average of $230 \mathrm{~mm}$ during 2010 and 2009, respectively. Combining irrigation and precipitation during the growing season, total water available for the irrigated treatments was 414 and $534 \mathrm{~mm}$ during 2009 and 2010, respectively. Average daily temperatures were similar during the growing season of $2009\left(27.0^{\circ} \mathrm{C}\right)$ and $2010\left(26.7^{\circ} \mathrm{C}\right)$, and were warmer than the historical average of $25.8{ }^{\circ} \mathrm{C}$. Though the 2 years of the study. Planting dates were 3 June 2009 and 24 May 2010; harvest dates were 21 August 2009 and 19 August 2010

average temperatures were similar between years, 2010 had an unseasonably cool and wet 7-day period approximately 1 month after emergence, which slowed crop growth.

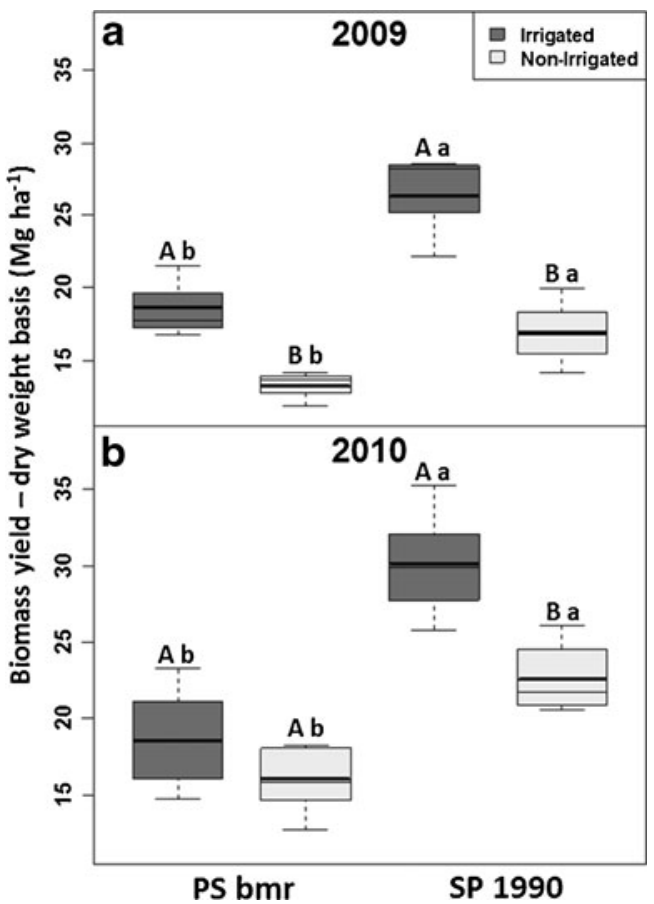

Fig. 2 Plant biomass yield for the $2009(A)$ and 2010 (B) growing seasons as affected by cultivar and irrigation. Cultivars are delineated by dashed lines while growing seasons are separated by solid lines. Statistical differences $(\alpha=0.05$, if present) due to irrigation within the same cultivar are represented by different uppercase letters; differences due to cultivar within the same irrigation treatment are represented by lowercase letters. In the box, the thick band represents the mean, thin band represents the median, box edges represent the 25th and 75th percentiles, whiskers represent the largest value within 1.5 times the interquartile range, and dots (if present) represent individual sample values outside of the whisker range 
Table $1 P$ values from ANOVA for sorghum properties during the two growing seasons of the study

\begin{tabular}{|c|c|c|c|c|c|c|c|c|}
\hline Treatment & Biomass & $\mathrm{ADF}$ & $\mathrm{NDF}$ & $\mathrm{ADL}$ & Cellulose & Hemicellulose & $\% \mathrm{CCE}$ & TEY \\
\hline \multicolumn{9}{|l|}{$2009^{\mathrm{a}}$} \\
\hline Irrigation $(I)$ & 0.005 & 0.005 & 0.032 & n.s. & 0.027 & n.s. & n.s. & 0.005 \\
\hline Cultivar $(C)$ & 0.045 & n.s. & n.s. & 0.011 & n.s. & n.s. & $<0.001$ & n.s. \\
\hline \multicolumn{9}{|l|}{$2010^{\mathrm{a}}$} \\
\hline$I \times C$ & n.s. & n.s. & n.s. & n.s. & n.s. & n.s. & n.s. & n.s. \\
\hline Irrigation $(I)$ & 0.024 & 0.03 & 0.002 & n.s. & 0.034 & n.s. & n.s. & 0.027 \\
\hline Cultivar $(C)$ & $<0.001$ & n.s. & n.s. & $<0.001$ & n.s. & n.s. & $<0.001$ & $<0.001$ \\
\hline $\mathrm{I} \times \mathrm{C}$ & 0.012 & n.s. & n.s. & n.s. & n.s. & n.s. & n.s. & n.s. \\
\hline Year $(Y)$ & 0.005 & 0.021 & 0.004 & $<0.001$ & $<0.001$ & n.s. & n.s. & 0.025 \\
\hline$I \times Y$ & n.s. & n.s. & 0.006 & n.s. & n.s. & 0.002 & n.s. & 0.008 \\
\hline$C \times Y$ & n.s. & n.s. & n.s. & n.s. & n.s. & n.s. & 0.017 & 0.015 \\
\hline$I \times C \times Y$ & n.s. & n.s. & n.s. & n.s. & n.s. & n.s. & n.s. & n.s. \\
\hline
\end{tabular}

${ }^{a}$ Year is a repeated-measures ANOVA comparing the 2009 and 2010 growing seasons

$A D F$ acid detergent fiber, $N D F$ neutral detergent fiber, $A D L$ acid detergent lignin, $\% C C E$ percent cellulose conversion efficiency, $T E Y$ theoretical ethanol yield, n.s. values not significant $(\alpha=0.05)$

\section{Sorghum Biomass Yields}

Overall biomass production ranged from 13.2 to $30.1 \mathrm{Mgha}^{-1}$ (Fig. 2, A and B). Leaves accounted for $24-36 \%$ of the overall plant biomass, though there was no difference due to cultivar or growing season (data not shown). Biomass yields were influenced by year of sampling, cultivar type, and irrigation treatment. More biomass was produced by both cultivars in 2010 compared to 2009 (Table 1). The SP 1990 cultivar was more responsive to conditions during sampling years and produced $22 \%$ more biomass in 2010 than in 2009, whereas PS $b m r$ only produced $8 \%$ more in 2010. SP 1990 produced more biomass than PS $b m r$ in 2009 (35\%) and
$2010(52 \%)$ regardless of irrigation. Irrigated plots had significantly greater biomass than the dryland plots, with a larger difference in 2009 (49\%) than in 2010 (26\%) (Fig. 2, $\mathrm{A}$ and $\mathrm{B}$; Table 1). A significant interaction between irrigation and cultivar occurred only in 2010 according to ANOVA. For example, deficit-irrigated treatment increased biomass in SP 1990 during both years, but only in 2009 for PS $b m r$.

\section{Biomass Chemical Composition}

Similar to the biomass yields, the chemical composition was significantly affected by sampling year, cultivar, and irrigation treatments (Table 1 and 2). When averaged across all

Table 2 Sorghum biomass chemical composition as affected by cultivar and irrigation during the two growing seasons of the study. Mean and standard error (in parenthesis) are shown

\begin{tabular}{|c|c|c|c|c|c|c|}
\hline Cultivar & Irrigation & $\begin{array}{l}\text { ADF } \\
\%\end{array}$ & $\mathrm{NDF}$ & $\mathrm{ADL}$ & Cellulose & Hemicellulose \\
\hline \multicolumn{7}{|l|}{2009} \\
\hline \multirow[t]{2}{*}{ SP 1990} & Irrigated & $38.4(1.1) \mathrm{A} \mathrm{a}$ & $62.2(0.8) \mathrm{A} \mathrm{a}$ & $3.1(0.3) \mathrm{A} \mathrm{a}$ & $35.3(0.8) \mathrm{A} \mathrm{a}$ & $23.8(0.3) \mathrm{A} \mathrm{a}$ \\
\hline & Non-irrigated & $31.2(1.7) \mathrm{B} \mathrm{a}$ & $53.3(3.8) \mathrm{B} \mathrm{a}$ & $2.5(0.1) \mathrm{A} \mathrm{a}$ & $28.7(1.7) \mathrm{B} \mathrm{a}$ & $22.1(2.1) \mathrm{A} \mathrm{a}$ \\
\hline \multirow[t]{2}{*}{ PS bmr } & Irrigated & $36.5(0.3) \mathrm{A} \mathrm{a}$ & $60.2(0.5) \mathrm{A} \mathrm{a}$ & $1.5(0.1) \mathrm{A} \mathrm{b}$ & $35.0(0.4) \mathrm{A} \mathrm{a}$ & $23.7(0.3) \mathrm{A} \mathrm{a}$ \\
\hline & Non-irrigated & $32.8(0.2) \mathrm{B} \mathrm{a}$ & $55.4(0.3) \mathrm{B} \mathrm{a}$ & $1.8(0.3) \mathrm{A} \mathrm{b}$ & $30.8(0.1) \mathrm{B}$ a & $22.6(0.4) \mathrm{A} \mathrm{a}$ \\
\hline \multicolumn{7}{|l|}{2010} \\
\hline \multirow[t]{2}{*}{ SP 1990} & Irrigated & $36.2(1.0) \mathrm{A} \mathrm{a}$ & $57.5(0.6) \mathrm{A} \mathrm{a}$ & $3.7(0.2) \mathrm{A} \mathrm{a}$ & $32.5(0.8) \mathrm{A} \mathrm{a}$ & $21.2(1.0) \mathrm{A} \mathrm{a}$ \\
\hline & Non-irrigated & $31.4(0.4) \mathrm{B} \mathrm{a}$ & $54.4(0.3) \mathrm{B} \mathrm{a}$ & $3.6(0.1) \mathrm{A} \mathrm{a}$ & $27.7(0.3) \mathrm{B} \mathrm{a}$ & $23.1(0.4) \mathrm{A} \mathrm{a}$ \\
\hline \multirow[t]{2}{*}{ PS bmr } & Irrigated & $35.0(0.6) \mathrm{A} \mathrm{a}$ & $57.0(0.3) \mathrm{A} \mathrm{a}$ & $2.6(0.1) \mathrm{A} \mathrm{b}$ & $32.4(0.6) \mathrm{A} \mathrm{a}$ & $22.0(0.4) \mathrm{A} \mathrm{a}$ \\
\hline & Non-irrigated & $30.9(0.4) \mathrm{B} \mathrm{a}$ & $54.3(0.4) \mathrm{B}$ a & $2.6(0.1) \mathrm{A} \mathrm{b}$ & $28.3(0.3) \mathrm{B} \mathrm{a}$ & $23.4(0.3) \mathrm{A} \mathrm{a}$ \\
\hline
\end{tabular}

Statistical differences $(\alpha=0.05)$ due to irrigation within the same cultivar are represented by different uppercase letters; differences due to cultivar within the same irrigation treatment are represented by different lowercase letters 


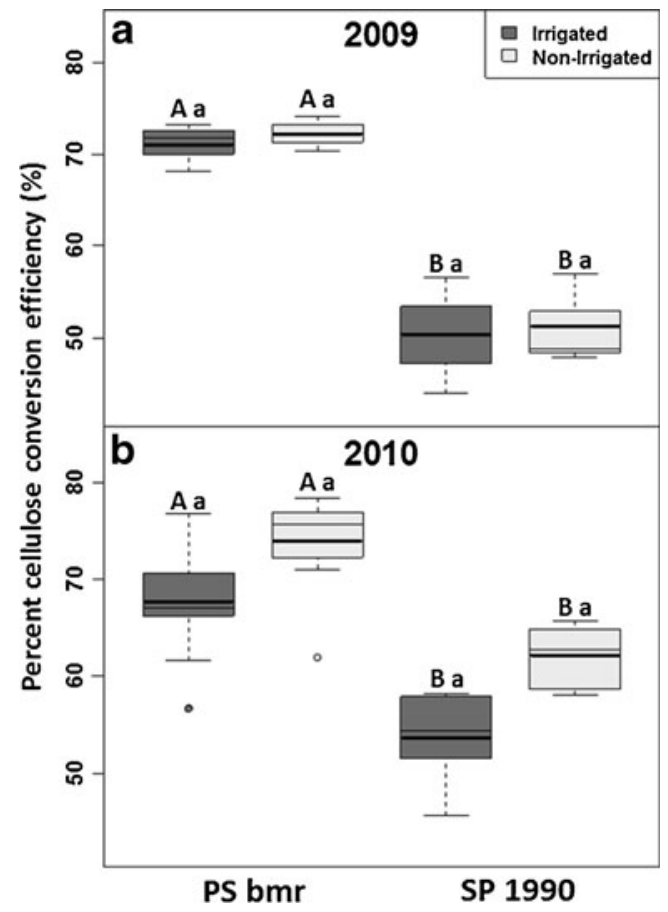

Fig. 3 Percent maximum ethanol conversion efficiency for the 2009 $(A)$ and $2010(B)$ growing seasons as affected by cultivar and irrigation. Cultivars are delineated by dashed lines while growing seasons are separated by solid lines. Statistical differences $(\alpha=0.05$, if present) due to irrigation within the same cultivar are represented by different uppercase letters; differences due to cultivar within the same irrigation treatment are represented by lowercase letters. In the box, the thick band represents the mean, thin band represents the median, box edges represent the 25 th and 75 th percentiles, whiskers represent the largest value within 1.5 times the interquartile range, and dots (if present) represent individual sample values outside of the whisker range

treatments, biomass from 2009 contained 4-7 \% more ADF, NDF, and cellulose, while ADL was $40 \%$ higher in 2010. No difference was found in hemicellulose between the growing seasons. As expected, the SP 1990 biomass contained higher lignin content (percent ADL) than PS $b m r$, but varied by year. For example, percent ADL in PS $b m r$ averaged $1.65 \%$ in 2009 and $2.6 \%$ in 2010 (Tables 1 and 2). The two cultivars did not show significant differences for ADF, NDF, cellulose, and hemicellulose. The irrigated treatment resulted in higher ADF (11-23\%), NDF (5-17\%), and cellulose (16-18\%) contents compared to the non-irrigated treatment for both cultivars (Table 2 ).

\section{Ethanol Conversion Efficiency and Yield Production}

Irrigation treatments had no significant effect on percent CCE during either growing season, and there was a significant interaction between cultivar and sampling year (Table 1). When averaged across irrigation treatments,
PS $b m r$ had significantly higher percent CCE than SP 1990 in both years, with a greater difference between cultivars in 2009 than in 2010 (Fig. 3, A and B). The percent CCE did not differ between years for PS $b m r$ but was significantly higher in 2010 than in 2009 for SP 1990.

When averaged across cultivars and irrigation treatments, $20 \%$ higher TEY was detected during 2010 than in 2009 (Fig. 4, A and B). Irrigation and cultivar influenced TEY differently depending on the growing season (Table 1). In 2009, deficit irrigation resulted in higher TEY compared to dryland for both SP 1990 (72\%) and PS $b m r(56 \%)$ cultivars, but within the same irrigation treatment, TEY did not differ between the cultivars (Table 1). In 2010, SP 1990 under irrigation had higher TEY than dryland SP 1990 (34\%) and PS $b m r$ under irrigation (28\%). In general, TEY was higher under deficit-irrigated $\left(2,640\right.$ to $\left.3,380 \mathrm{Lha}^{-1}\right)$ than the nonirrigated treatment $\left(1,600\right.$ to $\left.2,520 \mathrm{Lha}^{-1}\right)$ during both seasons. While statistical interactions were found between cultivar and year and irrigation and year, no three-way interaction was found for cultivar, irrigation, and year (Table 1). However, this study only occurred over two growing seasons; therefore, finding these interactions may be possible if this study occurred over a longer time period.

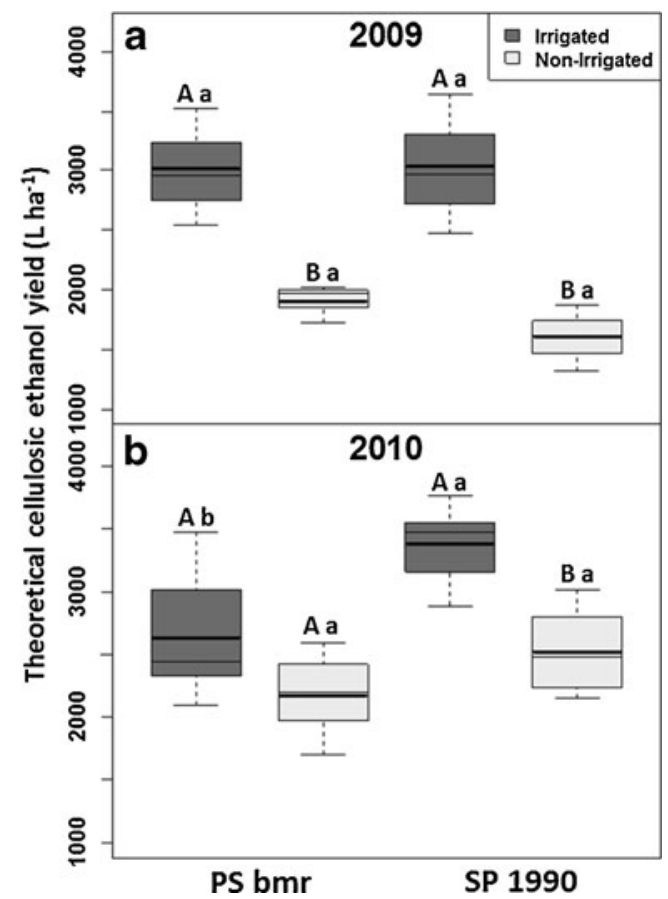

Fig. 4 Theoretical ethanol yield for the $2009(A)$ and $2010(B)$ growing seasons as affected by cultivar and irrigation. Cultivars are delineated by dashed lines while growing seasons are separated by solid lines. See Fig. 3 for box plot explanation 


\section{Discussion}

This study demonstrated the viability of sorghum to produce biofuel feedstock under water-limited conditions in a semiarid region such as the SHP. The biomass and cellulosic EtOH yields produced under both deficit irrigation and dryland conditions were comparable to other feedstock crops including sweet sorghum at various $\mathrm{N}$ rates in the SHP [29] and maize and switchgrass grown on marginal soil conditions in Nebraska [30]. In terms of biomass yield, the cultivars did not respond in the same manner to the total amount of available water (i.e., precipitation plus irrigation). When more water was available SP 1990 produced more biomass. However, this was not true for PS $b m r$, which showed similar biomass production under the irrigated treatment during both growing seasons, and no difference due to irrigation when more precipitation occurred during 2010. This indicates that while water seemed to be the limiting factor for SP 1990 [31], there could be other inherent genetic factors that limit biomass production in PS $b m r$ even when more water was available. Differences in yields between the cultivars concur with a report that $b m r$ mutation tends to lower stover yield in grain sorghum, though it is a positive in that it results in increased stover digestibility and quality $[16,17]$.

Our field studies support the finding that $b m r 12$ sorghums show higher cellulose conversion efficiencies associated with reduced lignin, which has been shown to be the most important factor in predicting EtOH yields [13, 24]. Though there was more lignin in biomass from the 2010 growing season, little difference was found in percent CCE between growing seasons, which suggests that other plant properties affected cellulose conversion to EtOH. ADF, NDF, and cellulose, which were slightly higher in 2009 compared to 2010, have been found to be negatively correlated to EtOH conversion efficiency [24]. Additionally, other properties not measured have been shown to affect fermentable sugar yield, including lignin (e.g., syringil/ guaiacyl ratios) and cellulose structure [32]. Also, while the pretreatment used here $\left(\mathrm{NH}_{4} \mathrm{OH}\right)$ is generally effective at delignification and removal of some hemicelluloses [33], the effectiveness of the pretreatment was not measured here. The properties measured (specifically ADL) in this study are often effective predictors of energy conversion from plant biomass, but the complexity of cell wall morphology and chemical structures cannot be discounted and likely contributed to differences in EtOH conversion. Although this study did not address the conversion of the hemicellulose fraction to $\mathrm{EtOH}$, it is also an important consideration for energy yields when using biomass as feedstock.

One of the important questions of this study was whether a cultivar with the $b m r 12$ trait (i.e., PS $b m r$ ) could overcome its reduced biomass yield potential compared to a higher- yielding cultivar with conventional cell wall composition (i.e., SP 1990). During a growing season with belowaverage precipitation for a semiarid region, the cultivars had similar TEY. When above-average precipitation occurred, the increased cellulose conversion efficiency associated with reduced lignin was not enough to overcome its reduced yield performance compared to an elite non-bmr cultivar. Thus, especially in regions such as the SHP where water availability is highly variable, it is critical to consider the ability of a crop to possess high biomass yield potential while maximizing energy production through efficient conversion processes. Overall, we demonstrated that a commercial $b m r 12$ containing sorghum cultivar PaceSetter $b m r$ showed improved composition resulting in higher ethanol conversion, but has lower biomass production capacity. Thus, continued breeding efforts for better agronomic performance of low-lignin (e.g., $b m r 12$ )-containing sorghum cultivars, specifically for enhanced biomass production, are warranted to realize the potential of sorghum biomass under semiarid and dryland environments.

In order to meet the current mandated biofuel production goals, different regions and agricultural systems need to be explored. Although water-limited regions, such as the SHP, cannot economically compete with more temperate regions in biomass and energy yields for biofuel feedstocks, this region holds potential to contribute to overall biofuel production. The sorghum cropping system described here under no irrigation or deficit irrigation levels serves as a platform from which to continue research leading to technological advancements (e.g., sorghum genetics, biomass pretreatment, microbial conversion efficiency, adapted crops) for sustainable biofuel production in this and other similar regions nationwide.

Acknowledgments We would like to thank the USDA-ARS Ogallala Aquifer Initiative for providing funding for this project, Dr. David Wester for input in statistical analysis, and laboratory personnel at the USDA-ARS for assistance in field and lab data collection.

USDA Disclaimer Mention of trade names or commercial products in this publication is solely for the purpose of providing specific information and does not imply recommendation or endorsement by the US Department of Agriculture. USDA is an equal opportunity provider and employer.

\section{References}

1. US Department of Energy (2005) Biomass as feedstock for a bioenergy and bioproducts industry: the technical feasibility of a billion-ton annual supply. Perlack RD, Wright LL, Turhollow AF, Graham RL, Stokes BJ, Erbach DC (Leads) U.S. Department of Energy, Oak Ridge, TN. Pub. No. DOE/GO-102005-2135. http:// www.osti.gov/bridge. Accessed 14 Feb 2012

2. US Department of Energy (2011) U.S. billion-ton update: biomass supply for a bioenergy and bioproducts industry. Perlack RD, 
Stokes BJ (Leads) U.S. Department of Energy, Oak Ridge, TN. Pub. no. ORNL/TM-2011/224. http://www.osti.gov/bridge. Accessed 14 Feb 2012

3. Cassman KG, Liska AJ (2007) Food and fuel for all: realistic or foolish? Biofuels Bioprod Bioref 1:18-23

4. National Agriculture Statistics Service (2007) 2007 census of agriculture. US Department of Agriculture, Washington D.C. http://www.agcensus.usda.gov/Publications/2007/index.asp. Accessed 16 Dec 2011

5. Allen VG, Brown CP, Segarra E, Green CJ, Wheeler TA, AcostaMartínez V, Zobeck TM (2008) In search of sustainable agricultural systems for the Llano Estacado of the U.S. Southern High Plains. Agric Ecosys Environ 124:3-12

6. Acosta-Martínez V, Lascano R, Calderón F, Booker JD, Zobeck TM, Upchurch DR (2011) Dryland cropping systems influence the microbial biomass and enzyme activities in a semiarid sandy soil. Biol Fertil Soils 47:655-667

7. Lee JA, Baddock MC, Mbuh MJ, Gill TE (2012) Geomorphic and land cover characteristics of aeolian dust sources in West Texas and eastern New Mexico, USA. Aeolian Res 3:459-466

8. Cotton J, Acosta-Martínez V, Moore-Kucera J, Burow G (2012) Early changes due to sorghum biofuel cropping systems in soil microbial communities and metabolic functioning. Biol Fertil Soils. doi:10.1007/s00374-012-0732-z

9. Polley HW, Johnson HB, Mayeux HS (1992) Determination of root biomasses of three species grown in a mixture using stable isotopes of carbon and nitrogen. Plant Soil 142:97-106

10. Rooney WL, Blumenthal J, Bean B, Mullet JE (2007) Designing sorghum as a dedicated bioenergy feedstock. Biofuels Bioprod Bioref 1:147-157

11. Saballos A (2008) Development and utilization of sorghum as a bioenergy crop. In: Vermerris W (ed) Genetic improvement of bioenergy crops. Springer Science + Business Media, New York, pp 211-248

12. Dien BS, Sarath G, Pedersen JF, Sattler SE, Chen H, FunnellHarris DL et al (2009) Improved sugar conversion and ethanol yield for forage sorghum (Sorghum bicolor L. Moench) lines with reduced lignin contents. Bioenerg Res 2:153-164

13. Lorenz AJ, Anex RP, Isci A, Coors JG, de Leon N, Weimer PJ (2009) Forage quality and composition measurements as predictors of ethanol yield from maize (Zea mays L.) stover. Biotechn Biofuels 2:1-8. doi:10.1186/1754-6834-2-5

14. Bout S, Vermerris W (2003) A candidate-gene approach to clone the sorghum brown midrib gene encoding caffeic acid $O$-methyltransferase. Mol Gen Genomics 269:205-214. doi:10.1007/ s00438-003-0824-4

15. Saballos A, Vermerris W, Rivera L, Ejeta G (2008) Allelic association, chemical characterization and saccharification properties of brown midrib mutants of sorghum (Sorghum bicolor (L.) Moench). Bioenerg Res 1:193-204. doi:10.1007/s12155-008-9025-7

16. Oliver AL, Pedersen JF, Grant RJ, Klopfenstein TJ, Jose HD (2005) Comparative effects of the sorghum bmr-6 and $b m r-12$ genes: II. Grain yield, stover yield and stover quality in grain sorghum. Crop Sci 45:2240-2245

17. Sattler SE, Funnell-Harris DL, Pedersen JF (2010) Brown midrib mutations and their importance to the utilization of maize, sorghum, and pearl millet lignocellulosic tissues. Plant Sci 178:229 238. doi:10.1016/j.plantsci.2010.01.001

18. Tew TL, Cobill RM, Richard EP Jr (2008) Evaluation of sweet sorghum and sorghum $\times$ sudangrass hybrids as feedstocks for ethanol production. Bioenerg Res 1:147-152

19. Bean B, McCollum T (2006) Summary of six years of forage sorghum variety trials. Texas Cooperative Extension and Texas Agricultural Experiment Station, Amarillo, TX. Pub No SCS-2006-04 2-06

20. Texas Alliance for Water Conservation (2011) TAWC ET. Texas Alliance for Water Conservation, Lubbock, TX. http:// www.depts.ttu.edu/tawc/. Accessed 13 Dec 2011

21. ANKOM Technology (1998) Method for determining acid detergent fiber. Ankom 200/220 Fiber Analyzer Manual, Fairport, NY

22. ANKOM Technology (1998) Method for determining neutral detergent fiber. Ankom 200/220 Fiber Analyzer Manual, Fairport, NY

23. ANKOM Technology (1998) Method for determining acid detergent lignin in beakers. Ankom 200/220 Fiber Analyzer Manual, Fairport, NY

24. Isci A, Murphy PT, Anex RP, Moore KJ (2008) A rapid simultaneous saccharification and fermentation (SSF) technique to determine ethanol yields. Bioenerg Res 1:163-169

25. Megazyme International Ireland Ltd (2011) Ethanol assay procedure, 02/11 ed, Wicklow, Ireland

26. Schuler ML, Kargi F (2002) Bioprocess engineering, 2nd edn. Prentice Hall, USA

27. Kim TH, Lee YY (2005) Pretreatment of corn stover by soaking in aqueous ammonia. Appl Biochem Biotechnol 121:1119-1132

28. R Development Core Team (2011) R: a language and environment for statistical computing. Vienna, Austria. http://www.R-project.org/. Accessed 11 Jan 2011

29. Tamang PL, Bronson KF, Malapati A, Schwartz R, Johnson J, Moore-Kucera J (2011) Nitrogen requirements for ethanol production from sweet and photoperiod sensitive sorghums in the Southern High Plains. Agron J 103:431-440

30. Varvel GE, Vogel KP, Mitchell RB, Follett RF, Kimble JM (2008) Comparison of corn and switchgrass on marginal soils for bioenergy. Biomass Bioenerg 32:18-21

31. Turhollow AF, Webb EG, Downing ME (2010) Review of sorghum production practices: applications for bioenergy. Oak Ridge National Laboratory, Oak Ridge. TN, pub. no. ORNL/TM-2010/7. http://www.osti.gov/bridge. Accessed 13 Oct 2010

32. Corredor DY, Salazar JM, Hohn KL, Bean S, Bean B, Wang D (2009) Evaluation and characterization of forage sorghum as feedstock for fermentable sugar production. Appl Biochem Biotechnol 158:164-179

33. Zheng Y, Pan Z, Zhang R (2009) Overview of biomass pretreatment for cellulosic ethanol production. Int J Agric Biol Eng 2:51-68 